Spring 1973

\title{
Preparing for the Future of Probate in America
}

Robert Whitman

University of Connecticut School of Law

Follow this and additional works at: https://opencommons.uconn.edu/law_papers

Part of the Estates and Trusts Commons, Legislation Commons, and the State and Local Government Law Commons

\section{Recommended Citation}

Whitman, Robert, "Preparing for the Future of Probate in America" (1973). Faculty Articles and Papers. 278.

https://opencommons.uconn.edu/law_papers/278 


\section{HEINONLINE}

Citation: 5 Conn. L. Rev. 557 1972-1973

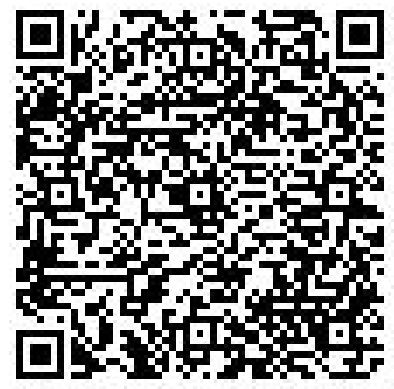

Content downloaded/printed from

HeinOnline (http://heinonline.org)

Mon Aug 15 17:34:06 2016

-- Your use of this HeinOnline PDF indicates your acceptance of HeinOnline's Terms and Conditions of the license agreement available at http://heinonline.org/HOL/License

-- The search text of this PDF is generated from uncorrected OCR text.

-- To obtain permission to use this article beyond the scope of your HeinOnline license, please use:

https://www.copyright.com/ccc/basicSearch.do?

\&operation $=$ go\&search Type $=0$

\&lastSearch $=$ simple\&all $=$ on\&titleOrStdNo $=0010-6151$ 


\title{
PREPARING FOR THE FUTURE OF PROBATE IN AMERICA
}

\author{
by Robert Whitman*
}

7 HE MOST important question that will be faced in the future 1 with regard to probate reform in America will be placing with the proper parties the responsibility for creating a redesigned probate system that will best serve the public interest.

Responsibility - the key to meaningful probate change in the future

If in America we do in the future come to properly place responsibility for planning for probate reform, we will do so for the first time.

Unlike the English probate system, probate practices in the United States have never developed nationally in a uniform and organized way. All our past efforts for reform have suffered from a lack of broad organization and planning. The common pattern in America has been to await some stimulus that causes an awakening to the inadequacies of our probate system and a dissatisfaction with our failure to plan for and institute meaningful change. Such a stimulus most recently occurred when the book How to Avoid Probale was published in the United States. There has followed a public awakening that has led to a voluntary acceptance of the task of attempting constructive change on the part of some individuals or groups that have the requisite knowledge about and interest in changing the present probate systems. Of course, however, these concerned individuals and groups have approached the planning task with their own needs and their own experience in mind.

*Professor of Law, University of Connecticut, School of Law; Professor Whitman serves as consultant to the Probate Administrator of the State of Connecticut. He conducted the National Fiduciary Accounting Study for the American Bar Association, Section of Real Property, Probate and Trust Law.

This article was prepared for the ANgLo-American LAw Review, a publication of Brunel University, Middlesex, England. Professor Whitman served as a Visiting Professor at Brunel University during the Fall, 1972. It is reprinted here with the permission of the ANGLo-AMERICAN LAw Review:

This article was also submitted to a special "future shock committee" appointed by the Council of Real Property, Probate and Trust Law Section, American Bar Association. The committee has been charged with developing formats for in-depth studies by Section members on the nature and structure of the practice of law within the Section's interest areas in the remaining years of the century. Probate and Property Newsletter, Dec. 1972, at 5. 
This haphazard pattern for planning for change can be seen in tracing the development of the Uniform Probate Code, which is currently the major piece of probate reform legislation being advocated in the United States.

More than thirty years ago, a law professor suggested that the American Bar Association, Section of Real Property, Probate and Trust Law, prepare a model probate code to encourage uniformity in probate legislation. His suggestion was accepted and this led to the development of the Model Probate Code, which was published in 1946. The Model Probate Code was not designed as a uniform statute to be enacted by all of the states, although it did influence probate legislation in some states. The Model Probate Code was drafted with little, if any, empirical study and did not contain major suggestions for sweeping change.

Some twenty years later, it was again suggested to the American Bar Association, Section of Real Property, Probate and Trust Law, that it cooperate with the National Conference of Commissioners on Uniform State Laws in revising the Model Probate Code and other existing uniform laws in the field of probate to create a Uniform Probate Code, designed for enactment by all of the states. This suggestion was accepted and led to the preparation of the Code by a group of lawyers and trust officers. The Code, drawing heavily on English practice, was promulgated by the National Conference of Commissioners on Uniform State Laws and approved by the House of Delegates of the American Bar Association in 1969.1

Coming with the Uniform Probate Code is a Joint Editorial Board. The primary task that has been undertaken by the Joint Editorial Board is to encourage the adoption of the Code. It has not encouraged new experimentation or new design of reforms, suggesting that presently the need for uniformity is the most important goal. ${ }^{2}$

1. See Fratcher, Estate Planning and Administration Under the Uniform Probate Code, 110 Trusts \& Estates 5 (1971).

2. The Joint Editorial Board publishes a newsletter, UPC Notes, in which suggestions for changes in the Code are discussed and evaluated. A suggestion by the Arizona Law Revision Commission to modify the Code's intestacy provisions was deemed to be "unfortunate" on the theory that "the Arizona people disregarded the important purpose of achieving uniformity among the states on rules of heirship." UPC Notes, Oct. 1972, at 9.

UPC Notes, March, 1973, at 3, reported on a speech by the Board's Dircctor and the Chief Reporter of the Code, Professor Weilman of the University of 
Where then can we expect new probate reform proposals to come from in the future? Must our old "wait until someone wakes us up" pattern continue? Undoubtedly, the American Bar Association, Section of Real Property, Probate and Trust Law, can be expected to continue its fine work. Indeed, in I97I, it again entered the reform field by sponsoring a national study on fiduciary accounting. ${ }^{3}$ But the position I wish to put forward in this article is that we should not be satisfied to allow the task of planning for reform to continue in this informal way.

The reforms in probate that we realize we need today are far different than those that we visualized as being needed only a few years ago. At a time when the major concern of reformers was the proper formulation of the rule against perpetuities, ${ }^{*}$ perhaps our uncoordinated informal machinery for preparing for change was adequate. Today, however, we face probate reform with a different perspective.

It seems quite clear now in looking towards the future that we must be primarily concerned with meeting the reasonable demands of the public. This may mean that we should reconsider the use of some of our most basic techniques. Does it make any sense to continue to recognize the validity of a holographic will, as the Uniform Probate Code does? In states that do not recognize that instrument, the Code would seem to advocate a step backward.5 Indeed, in the

Michigan Law School. In speaking of the Code's controversial provisions for the spouse's election, Professor W'ellman expressed concern that "worthwhile goals of the Code might be jeopardized by 'academic skirmishing' over these relatively unmanageable and unimportant features of the Code."

For arguments that these Code provisions should be reconsidered, see Clark, The Recapture of Testamentary Substitutes to Preserve the Spouse's Elective Share: An Appraisal of Recent Statutory Reforms, 2 ConN. L. REv. 513 (1970).

3. See Whitman, National Fiduciary Accounting Study, 7 Real. Prop., Pron. \& Trust J. 467 (1972).

4. See Powell, Changes in the New York Statutes on Perpetuities and Accumulation: A Report and a Proposal, 58 Colum. L. Rev. 1196 (1958).

5. See letter from Donald S. Buzard, First Vice President of the First Wisconsin Trust Company to George A. Picknell, Senior Vice President of The Ohio Citizens Trust Company, dated February 28, 1973. In the letter, which compares the Wisconsin Probate Code to the Uniform Probate Code, Mr. Buzard states:

There are several areas in which the Wisconsin Bar feels its code is superior to the UPC. We did not adopt their holographic will provision because this broadens the opportunity for fraud, confusion and will contests. We have enough problem with interlincations in existing wills, and notes and letters purporting to dispose of tangible personality, with- 
future, perhaps the will as we know it should be replaced by a computer punch card. In the future, should simple estate planning be carried out through specialists or through an office of the probate court? Should ownership concepts between spouses be radically altered to avoid the need for involved estate planning? Should there be an unlimited marital deduction for estate tax purposes ${ }^{6}$ and, if so, will this mean that in most cases a surviving spouse will be able to avoid probate procedures completely with respect to the estate of the deceased spouse?

When we look to the future and plan for probate procedures for decedents' estates, clearly the need appears to be the delivery of legal services in the most efficient and effective manner. Called for are the following three major achievements:

1. fast probate,

2. economical probate, and

3. protection of the interested parties.

The first, the need for fast probate, is by far the one that is most clearly understood today and the simplest to gain. The very sound, and much needed, flexible provisions of the Uniform Probate Code (which allow for informal probate and independent administration) rightly provide for minimal contact with the courts of probate where no questions are raised. Under the Code, if all interested parties agree, fast probate is obtainable.

out broadening this area. We think the better rule is to require witnesses, even for a handwritten will.

Mr. Buzard further comments on other areas of the Code, including the concept of vesting of title in the Personal Representative, the concept of durable power of attorney, intestacy provisions, supervised proceedings, claims, registration of inter vivos trusts, the "self-proved" will, and bonding provisions. At the outset, he states, "Unfortunately there are no written reports, articles, or memoranda criticizing Uniform Probate Code, of which I am aware." But see, e.g., Cal. State Bar, Analysis and Critique of the Uniform Probate Code (March, 1973). (The report, compiled under the direction of the Bar's committee on Probate and Trust Law, after a three year study of the UPC and California laws, recommends against the adoption of the Code in California.); Symposium on Probate Law, 2 ConN. L. Rev. (1970) including critical comment by Charles T. Parker, Esq., regarding the Code's notice provisions. See also, Waggoner, A Proposed Alternative to the Uniform Probate Code's System for Intestate Distribution among Descendants, $66 \mathrm{Nw} . \mathrm{U}$. L. REv. 626 (1971).

6. A tax free interspousal transfer rule has been advocated. See A.L.I. Estate and Gift Tax Project, 3 Real Prop., Prob. \& Trust J. 111, 119-122 (1968). 
But the remaining goals of economical probate and protection are not now being adequately accomplished. To a large extent, I believe, little has been done to achieve these goals because the group most directly able to deal with the problem-the judges of probate-has not adequately organized and attempted broad studies that would allow it to offer constructive suggestions for change.

The cost of probate is undoubtedly most substantially affected by the need for a lawyer. The answer to the question, when is a lawyer needed in probate, must depend on the extent of the services that are provided by courts of probate and the courts' requirements that a lawyer be employed.7 Also resting with the courts of probate is the task of determining how best to protect interested parties. Although the probate courts have traditionally deferred to the Bar and the legislature to set probate standards, undoubtedly the courts are far better equipped to determine these matters which clearly lie within the judicial sphere.

In those states of the United States in which the court of probate is always very much involved in supervising the administration of each estate, the court is involved, at least in theory, to insure the protection of the interested parties. Protection includes court audit of accountings and court approval of fiduciary and attorney fees. ${ }^{8}$ In

7. Several states by statute specifically prohibit court personnel from assisting in filling out probate forms. The Supreme Court of Wisconsin has required an executor to be represented by an attorney before the probate court to gain court approval of an accounting, even though all parties were competent and consented to the accounting. Baker v. County Court, 29 Wis.2d 1, 138 N.W.2d 162 (1965); Annot., 19 A.L.R. 3d 1104 (1968). The Wisconsin court cited the administrative difficulties that would be presented to the court if attornejs were not emplojed.

This attitude should be contrasted with the attitude in Great Britain, where more than twenty percent $(20 \%)$ of the probate applications are handled through the Office of Personal Application, without the need for an attorney. See Fratcher. Probate Can Be Quick and Cheap, 1968 ). From intervicws with persons at the Personal Application Department, the author believes the percentage to be on the rise.

Hopefully, in the future, the development of group legal services in America will lead to the arailability of adequate representation for individuals before the courts of probate at a reasonable cost.

Another means of funding the cost of attorneys would be to allow a graduated credit against death taxes due, so that the cost of representation would not be borne directly by the estate. The institution of such a credit would encourage the employment of an attorney, thereby relieving the administrative burden on the courts and providing protection to the parties.

8. For a discussion of the inadequate performance of courts of probate in the 
England, and in Code jurisdictions (or in jurisdictions with procedures similar to the Code), the court protects the interest of the parties only if called upon to do so by the parties. This means that in practice protection of the parties in these jurisdictions can be insured only by overall supervisory measures taken by the courts of probate. The court must see to it that the parties understand (a) their situation, (b) that they may call upon the court if they wish to do so, and (c) that they must call upon the court to obtain any court protection. ${ }^{9}$

Therefore, in every jurisdiction of the United States, the courts of probate have the power to control both the cost of probate and the amount of protection the parties actually obtain. It is these courts that can institute the most effective and far reaching reforms.

Given this reservoir of power resting in the courts of probate, one might expect that the courts would now be in the center of organized movements for probate reform. Unfortunately, however, this has not been the case at all. Some of the variety of reasons that explain why courts of probate have not taken on responsibility include historical patterns, lack of competence, lack of organization, lack of understanding that reform in the public interest is a concern of the judiciary as well as the Bar and the legislature, lack of understanding that judges as well as lawyers, trust officers and legislators can determine the proper place of courts in the probate system, lack of time, and inertia.

Until very recently, courts of probate have been virtually out of the reform movement in America. For the future, however, the beginnings of a changing pattern can be seen.

Courts of probate have now begun to activate

Already signs of activity can be seen. Consider the problem of the "lazy" fiduciary and/or attorney.

What remedy is available to beneficiaries whose fiduciary and/or counsel unduly delay the settlement of an estate? Without active court intervention such a fiduciary or attorney can create an intolerable situation for beneficiaries.

Under the Rules for the Surrogate's courts in the Second Judical

areas of review of accountings and approval of fees, see Whitman, Misconceptions Regarding Probate Reform, 111 TRusts \& Estates 392 (1972).

9. One finding of the National Fiduciary Accounting Study is that much work must be done in America to help persons interested in an estate to properly 
understand their position. Consider the following excerpts from the Study:

The notice sent to the beneficiaries concerning the court accounting is generally quite inadequate and indecd, misleading. One typical notice form reads, in part:

Notice is hereby given that the accounts of the subscriber, deceased, will be audited and stated by the surrogate and reported for settlement to the ...

Your presence is not necessary at the above time unless you care to enter some objection to the accounting or to the allowance of fees requested.

From correspondence received by the study and intervicws held, it is clear that the standard notice. forms in use are totally inadequate and do, in fact, mislead persons to whom fiduciaries are responsible. Often, the standard of practice set by a fiduciary with regard to notice is higher than that required, since the fiduciar; will furnish a copy of the account to persons to whom he is responsible, although he is not required to do so by the statutes.

Consider the following sample responses to inquiries regarding practices of sending notice and providing copies of an accounting to persons to whom the fiduciary is responsible:

"The accounting is an ex parte matter and no report or copies of the filed accounting must be sent to the beneficiaries or heirs."

"The beneficiary has no role in the accounting. He does not receive a copy of the accounting unless he requests it. The beneficiary is given a notice of hearing. The beneficiary is not made aware that he must protect his intercsts."

"Your next question is whether or not in actual practice the beneficiary of an Estate is informed of his right to an account upon request. Normally, I would think he would be unaware of this right. As a practical matter, if a beneficiary is suspicious or dissatisfied with the handling of the Estate, he would approach the Exccutor or Administrator and probably not receive this information, particularly where the fiduciary is an individual. However, if he secks the advice of Counsel, which he might normally do, if he is dissatisfied, this probably would be the first place that he would be aware of his right to request an account."

"No, there is no requirement that the beneficiaries, heirs or devisees receive copies of the accounts. Some attorneys send them copies, which is only logical as there is a date for final hearing sct at which time any party in interest may object to the accountings. Yet some attorneys do not send them. It is our practice to make up cnough copics for each party in interest and request the attorncys to send copies to each."

"Although the statute does not specify that beneficiaries receive a copy of the accounting, it is our practice to furnish them with an accounting so that they can be better appraised of what is going on in the estate."

Failure to make provisions for adequate notice to persons to whom the fiduciary is responsible takes on crucial significance when it is realized that, by and large, the court of probate does not actually review accounts unless a complaint is lodged by a person to whom the fiduciary is responsible. And a person to whom the fidu. ciary is responsible does not review the accounting because (1) he is not told he 
Department in New York City, ${ }^{10}$ a statement must now be filed by the executor or administrator for any estate that has not been fully distributed (or a final accounting filed) within a fixed period of time from the issuance of letters testamentary or letters of administration, and the statement, in addition to supplying other data, must contain a statement of the reason why the estate has not been fully distributed. The failure to file the statement will be considered by the court on application for commissions or legal fees and may constitute a ground for disallowance of commissions or fees.

In other courts of probate the computer is being employed to keep track of all filed estates, so that delinquent fiduciaries can be identified and contacted by the court. ${ }^{11}$

Consider the problem of a beneficiary who may receive a fiduciary accounting and be unaware of its significance. A rule in the proposed Connecticut Probate Practice Manual ${ }^{12}$ provides:

Notice to beneficiaries: The purpose of this account is to inform interested parties of the manner in which the fiduciary has handled the estate during the accounting period. It is your responsibility to carefully inspect the account to determine if you have any objections to anything in the account. Where any doubt exists in your mind as to the accuracy or the propriety of anything in the account, or if you do not feel that you are capable of properly reviewing the account yourself, you should consult an attorney to in-

must do so to protect his interests, (2) he is not given a copy of the accounting, and (3) he is made to believe that the account is being audited for him by the court of probate.

Whitman, National Fiduciary Accounting Study, 44-46 (unpublished full text available through American Bar Association, Section of Real Property, Probate and Trust Law).

From interviews in England, the author is of the opinion that a similar problem of inadequate disclosure of rights exists in England.

10. Uniform Rules for the SURrogate's Coukts in the Second Judicial DepartMENT, $§ 1830.25(\mathrm{~b})(3)$, (effective Sept. 2, 1972).

11. This practice has been developed by the Probate Administrator of the State of Connecticut. See also Hensley, Punched Cards Produce Progress in Probate Code, 48 ABA Journal 138 (1962).

12. The Proposed Connecticut Probate Practice Manual is available through the office of the Probate Administrator, Hartford, Connecticut. Another rule in the Manual would require early formal notification of rights by the fiduciary to persons interested in the estate. PHIL. ProB. CT. R. 63.1(c) also provides for expanded notice to beneficiaries in connection with fiduciary accountings. 
sure the protection of your rights. If you have any objections, you must express them to the court of probate at the hearing on the account. If you do not express objections to the account, the court of probate may approve the account as submitted.

In the field of fiduciary accounting, it is clear that there is a great deal more that must be done to upgrade and standardize fiduciary accounts, so that they can be properly understood by beneficiaries. ${ }^{13}$ Here again, the courts of probate are the logical institution to carry out, or cooperate in, a study that will produce the needed improvements.

The production of manuals of practice which clarify, unify, and formalize procedures for probate practice is yet another vital area for court of probate involvement. ${ }^{14}$ Manuals are needed not only for lay persons and practitioners, but also for the courts.

To the extent that courts determine that an attorney should be required to be employed in particular probate mqtters, the availability of clear guides for the attorney will lower the amount of his time required and, correspondingly, lower the cost of his services.

\section{Conclusion}

Adequate solutions to the types of problems mentioned above cannot be easily arrived at. The most important point to recognize for the future is that, thus far, there has not been an adequately organized effort for reform. Focusing on the responsibility of the probate courts in this area should begin to produce wanted changes.

13. See Whitman, The National Fiduciary Accounling Study: A Report, 111 Trusts \& Estates 878 (1972).

14. There has been an increased awareness of the need for manuals. In 1972, the Association of Continuing Legal Education Administrators published a Uniform Probate Code Practice Manual. Several Bar Associations have also undertaken the creation of such works. See 112 Trusts \& ESTATES 279 (1973) (reporting that the Trusts and Estates Section of the New York State Bar Association has undertaken to author and publish on behalf of the State Bar a book, "How to Live . . . and Die ... With New York Probate." It will be written in layman's language and is designed to be of interest to the Bar and to the general public). Preferably, such a book should be published under the auspices of the court of probatc. If the book were published by the court it could better indicate in what cases an attorney is required and what steps, if any, the court will take to insure that a proper fee is charged. It could also better indicate the function of the court and the extent to which the court can protect the interests of the parties. 
Recognition of the role that organized courts of probate can and should play in connection with reform should also provide insight into the future development of these courts. As needed organization takes place, old style courts manned by part-time, lay judges should rapidly disappear. Probate Court Administrators in each state should provide the required organization for each state's probate courts. ${ }^{15}$ National task forces of judges or administrators should be prepared to study perplexing problems (on their own, or in cooperation with other interested groups), suggest revisions in procedure, and arrange to test the proposed revisions to actually determine their effectiveness. Ultimately such task forces should be in a position to promulgate nationally uniform standards for all of the courts of probate in the United States.

The trends in this direction in America are already quite clear. As they develop they will bring to courts of probate in America the same sense of responsibility for revising procedures that is now lodged in the court of probate in England. In time, a consolidation or responsibility in the courts of probate in America should produce probate courts that are truly responsive to the public need.

15. See Whitman, The Concept of a Probate Court Administrator - A Flexible System for Court Reform, 111 Trust \& Estates 12 (1972). See also Appendix. 


\section{APPENDIX}

The following material indicates the author's view that at the time of preparation of this article, for political reasons Connecticut has taken a giant step backwards in advancing the cause of creating a probate system that operates in the public interest. 1973:

J. Zaiman, Probate Setıp Due for Change, The Hartford Courant, April 18,

The General Assembly is preparing to approve legislation that would remove Superior Court Judge Jay E. Rubinow of Minchester as administrator of the state probate court system.

If the bill is approved by the Republican-controlled assembly as appears likely, Judge Rubinow would become an active Superior Court judge and would no longer have anything to do with the probate courts.

The legislative Judiciary Committee, it was learned Tuesday, has approved a bill giving Chief Justice Charles S. House the authority to appoint an administrator of the probate court system from among the elected probate judges in the state.

Under the present system, the probate court administrator is a Superior Court judge appointed by Associate Supreme Court Justice John P. Cotter, who is chief court administrator for the state.

Chief Justice House would have the authority to appoint or dismiss the chief probate court administrator.

If a probate judge named as probate court administrator is defeated in an election, he would lose his post as administrator of the probate court system.

The probate judge named as probate court administrator would continue to serve as probate judge in his district.

There is no appropriation attached to the bill, it was learned, which means that the probate judge named as court administrator will not get any extra compensation for his additional work. The bill would be effective October 1 .

A Judiciary Committee spokesman said the proposed change was approved by the committee "to bring the probate court system into line with the other courts in the state."

He noted that the chief judge of the Circuit Court system is a Circuit Court judge, that a Common Pleas Court judge heads the Common Pleas Court bench, and that a Superior Court judge is chief judge of the Superior Court system.

Judge Rubinow has been administrator of the state probate court system since July 1, 1967, when the General Assembly made extensive changes in probate court opcrating systems in the state, including adoption of legislation designating a Superior Court judge as head of the probate system.

Letter dated April 19, 1973 from Robert Whitman to The Honorable Gcorge C. Guidera (Senate chairman, Judiciary Committec) and The Honorable James F. Bingham (House chairman, Judiciary Committec) copies to: Governor Thomas J. Meskill and Chief Justice Charles S. House. 
RE: Proposed legislation concerning The Office of Probate Adminis. tration

Gentlemen:

This letter concerns a report in the Hartford Courant, dated April 18, to the effect that the General Assembly is preparing to ap. prove legislation that would provide for the appointment of a Judge of Probate as Probate Administrator in place of a Superior Court Judge.

The enactment of such legislation would clearly be detrimental to the interests of people of this State.

I can firmly attest to this fact on the basis of my experience over the last seven years. During that time, $I$ have served as a law professor at the University of Connecticut School of Law, where my major teaching interest has been probate; I have served as Director of the Commission to Study and Revise the Probate Laws of the State of Connecticut and $I$ have served as consultant to the Probate Administrator. I have visited each of our Courts of Probate and I have stud. ied and written about these Courts and about Probate Courts throughout the United States. I have conducted a national study on Probate Courts for the American Bar Association.

The opinion that I render to you - that the appointment of a Judge of Probate as a Probate Court Administrator would be clearly against the public interest - is a judgement based on my personal knowledge and experience and is given solely in my individual capacity. It is divorced from any political considerations, any political views I may hold, or any personal feelings I have for the current Probate Administrator or any of the Judges of Probate. It is a view that would, I believe, be affirmed by any objective non-political person who is knowledgeable in the field of Probate.

You will immediately understand why a Judge of Probate cannot properly serve as the Probate Administrator when you consider the unique position he holds.

Unlike any other judges in our State system, Judges of Probate are not salaried employees of the State. Speaking in general terms, in Connecticut a Judge of Probate, once elected, establishes his own "probate business". He earns his income from fees paid on the cases brought before his court. Without direct supervision, he establishes his own work hours, hires personnel, purchases equipment and establishes court procedures.

Prior to the establishment of the Office of the Probate Administrator and the imposition of the assessment system (which, on a graduated scale, assesses the Judge of Probate and provides a retirement fund for Probate Court personnel) Judges of Probate were totally free to manage the operation of their courts in any way that they saw fit. Bound together in the organization known as the Probate Assembly, it is commonly known that in 1967, when the Office of Probate Administrator was created, they firmly opposed the imposition of any supervision by a Probate Administrator, particularly anyone other than a Probate Judge. It is also commonly known that at that time the General Assembly rose above politics to establish the Office 
of the Probate Administrator and staff it with a Supcrior Court Judge to prevent and curb the abuse of the Probate Court system by any Probate Judge. The present Probate Administrator is neither a Dcmocrat nor a Republican - he is a Judge of the Superior Court. From the legislation creating the Office of Probate Administrator, it is clear that the General Assembly charged the Administrator with the protection of the public interest by working to improve the quality of the services of the Judges of Probate to the people of this State.

Upon the creation of the Office of the Probate Administrator and the commencement of the independent audit program, the need for the existence of an independent Administrator immediatcly became clear.

The Office of the Probate Administrator, charged by the General Assembly with the efficient operation of the Courts of Probate and with the duty of auditing, had found and checked numerous irregularities in the administration of the Courts of Probate. Audit has revealed some cases of unlawful charges being imposed by Judges of Probate on the public, cases of improper deductions of expenses of office by Judges, causing a loss of substantial amounts to the State and improperly allowing substantial excess income to the Judges, cases of extreme neglect of Office by Judges of Probate, and cases of irresponsible spending on the part of Judges of Probatc, to the point where the Probate Administrator has recently informed the Judiciary Committee of the General Assembly that on the basis of a statistical analysis, he now doubts the integrity of the retirement func. Accordingly, the Probate Administrator has suggested corrective legislation.

Undoubtedly, the large majority of our 125 Probate Judges are honest and devoted men. But as must be the case with a system that involves far too many judges (many of whom are totally inexperienced and not legally trained), these judges must be properly supervised if the interests of the public are to be protected. How can it be cxpected that a Judge of Probate will properly perform the audit function of the Office of the Probate Administrator? Can a Judge of Pro: bate audit his own accounts? Can a Judge of Probate disallow improper expenses or move to halt unlawful practices carried out by himself or by a fellow Probate Judge and a fellow member of the Probate Assembly? How can a Judge of Probate, whose income is dependent upon the preservation of our present antiquated and $\mathrm{cx}$ pensive Probate system, objectively report on the future development and improvement of our Probate Court system to the General Assembly?

A move to appoint a Judge of Probate as Probate Court Adminis. trator could only be viewed as being solely politically inspired and clearly against the public interest. An interruption in the present Administration of the Office would imperil the successful conclusion of all of the programs that the Office has instituted at the mandate of the General Assembly. This would include the completion of the Probate Practice Manual and Probate Practice Book, both of which are in the final stages of development, the production of uniform forms for use in all the Courts of Probate and the data processing program, which has been successfully implemented to monitor the 
administration of estates in order to speed up any estate that is not being processed promptly. Each of these programs, and others, have been well received and have advanced the public interest and improved the quality of Probate service to the pcople of this State.

With the above information and with additional information which can be gained from the Office of the Probate Administrator, I am confident that the Judiciary Committee will undertake a reexamination of its recommendation for change. The unique position of Judges of Probate within our system reveals that, unlike other branches of our Judiciary, it would not be proper for the General Assembly to provide that these Judges should supervise themselves. In undertaking such a reexamination of its recommendation, I would hope that the Judiciary Committee would solicit the opinion of the Chief Justice of the State of Connecticut, to whom a copy of this letter is being sent. Since the Chief Justice shares with the Legislature and the Governor the responsibility for the proper supervision of the Courts, his recommendation to the Judiciary Committee on this matter would be most important and should be sought. I would also respectfully suggest that it would be appropriate for the Chief Justice to make a public statement on this matter, which so greatly effects the judicial system of this State.

The recent passage of new intestacy legislation by the General Assembly clearly advanced the public interest in the probate field and demonstrated a sincere desire on the part of the General Assembly to meet its obligation to serve the public interest. The initial suggestion for that legislation had its origins from work done in cooperation with the Office of the Probate Administrator over five years ago. For that office, charged by the General Assembly to report to it con. cerning suggestions for statutory change, has served as an agency for creating new ideas and concepts and for refining new ideas and concepts put forward by Legislators, Judges of Probate, the Statc Tax Department, the Bar and other interested groups.

The work of the Office has received national attention and na. tional acclaim. The people of the State of Connecticut are entitled to have an Office of its calibre. A Judge of Probate, earning his livelihood on the basis of the present overly expensive system, beholden to his colleagues and unpaid for his efforts as Administrator, cannot carry out the functions of the Office of Probate Administrator in a proper manner.

Letter dated April 19, 1973, from The Honorable Arlene Mooney, Judge of Probate, District of Granby, to the Honorable Thomas J. Meskill, Governor, State of Connecticut:

\section{Dear Governor Meskill:}

With reference to your brief but pleasant visit before the Probate Assembly yesterday, I am sorry that there was not time for an ex. change on the merits of the bill reported in The Hartford Courant about which you expressed your approval.

Since the bill was not introduced by the Probate Assembly and since no one at yesterday's meeting claimed authorship, I think you 
should know that there are some Probate judges who do not agree with the principal that Judge Rubinow's office should be replaced. On the contrary, some of us, myself particularly, feel rather strongly that virtually the only encouraging things to emerge from the Probate Court System in the past few years have been the result of the efforts of Judge Rubinow's office and have come in spite of the open hostility of the Administration of the Probate Assembly.

To replace Judge Rubinow's office with someone from the Probate system - perhaps even a layman, since this represents half of our Probate Judges - would be, in my opinion, a sorry step backward. The Probate System is not comparable to the other parts of our judicial structure - Probate Judges are elected and are, obviously. part of the political process - they are not on tenure; many of them (myself included) look to their law offices for main support and of necessity consider the Probate Judgeship in its part-time aspect. To select from this group an overall Administrator does not make sense. To select from the Superior Court bench does.

Since the Probate Judges in Assembly, or otherwise, have not had the opportunity to review the proposed legislation, I would ask that you delay any approval until such time as this matter can be thoroughly reviewed and all of its ramifications studied.

B. Conrad (Politics Writer), Chief Justice MIum on Court Bill, The Hartford Times, April 25, 1973:

The state's chief justice denied comment today, and in his silence spoke volumes, about a bill requiring him to name a probate judge to oversee the probate courts.

Chief Justice Charles $H$. House of Manchester said he had not seen the bill and knew only what he had read in the newspapers about it.

The chief justice does not ordinarily offer opinions on pending legislation unless the judiciary is affected, as is the case in the probate bill.

But the report by the chief justice that he couldn't say anything on this bill because he hadn't seen it could only mean that the legislature had not consulted with him, told him what it had in the works, or sought his reaction.

It also meant that up to now, the governor's office had similarly kept the chief justice out of the picture despite his expressed wish a couple of months ago that there be more communication on proposals cutting across the lines of government.

That was part of Chief Justice House's message to a joint session of the General Assembly in February.

Historically, the probate courts are creatures of the General Assembly and can properly be regulated by the legislature. But in 1967 a modernization act put the probate system under the administration of a Superior Court judge.

Superior Court Judge Jay E. Rubinow of Manchester had held the job since the system went into effect. A Democrat, he would be relieved of the probate assignment if it is adopted. 
Then, under its provisions, Chief Justice House would name one of the 125 probate judges as administrator of the probate system. The appointing power would no longer belong to the chief court administrator-presently Justice John P. Cotter, who happens to be a Democrat.

Chief Justice House, a leader in his days as a legislator, suggested in this session of the General Assembly that each branch of government be kept separate and distinct but that where legislation involved the judiciary it was -appropriate for representatives of the two to consult. Ditto if the proposed legislation involved the executive and the judiciary.

A University of Connecticut law professor, Robert Whitman, objected last week to the bill giving the supervision of the probate system to one of its judges.

He suggested that Chief Justice House might want to say something about the proposal. The chief justice's response today killed that notion, however. Whitman, incidentally, is also consultant to the probate administrator under the present law.

The probate bill will be presented first in the House of Representatives, bearing the endorsement of the judiciary committee.

House Approves Bill Switching Chief of Court, The Hartford Courant, May 1, 1973:

A bill which would replace the present Superior Court judge with a Probate Court judge as chief administrator of the Probate Court was approved Monday in the state House of Representatives.

The measure was sent to the Senate on a vote of 122 to 16.

State Rep. James T. Healey, R-Waterbury, one of the bill's op. ponents and a specialist in Probate Court matters, claimed the bill "cuts the guts" out of the 1967 legislature's Probate Court reform law.

Healey said a Superior Court judge was made chief administrator in the 1967 reform measure because the job requires audits of the individual Probate Court operations. A probate judge, said Healey, should not be auditing his own operations and those of his fellow probate judges.

He said probate judges are "in a sense independent entrepre. neurs" whose income is from fees tied to the amount of business he gets in his court.

Proponents said an elected official like a Probate Court judge should not be subject to review of an appointed official like a Superior Court judge. Instead, they argued, a probate judge should be respon. sible to those who elect him.

Final Statement by Professor Robert Whitman Regarding Legislation Ending the Independent Office of Probate Administrator, dated May 2, 1973:

After learning that the House of Representatives voted this week 122 to 16 in favor of the bill to end the independent Office of Probate Administrator, I was inclined to let the inevitable happen without my further comment. I have already written at length that this bill, which apparently will be overwhelmingly approved, is clearly against the public interest. 
However, the receipt of a copy of a letter to the House Judiciary Chairman from a Judge of Probate convinces me that it is my public duty to make one more final statement on this mattcr.

Judge Zittel is a Republican Judge of Probate from the District of Lyme. His letter was unsolicited by me. He has granted me permission to release it. It is attached hereto.

I understand that at least one other Judge of Probate has written the Governor that the independent Office of the Probate Administrator has been the best thing to happen to probate in Connecticut in years.

It seems vital that the public once more be made to understand that the proposed bill is being adopted without any consideration as to what I have said, what these Judges of Probate are saying, or what an examination of the records of the Probate Administrator would reveal.

This bill is being passed without public hearing, without testimony of the Probate Administrator, without a request from the Judiciary and without concern for the obvious results.

I have previously stated that although the large majority of our 125 Probate Judges are honest and devoted men, I believe that an examination of the records of the Probate Administrator would reveal:

1. Cases of irresponsible spending by judges that deprive the State of its revenue;

2. Cases of irresponsible conduct on the part of judges who control their work hours and procedures;

3. Cases of improper accounting for funds; and

4. Cases of unlawful charges to the public.

The response of the leadership of the General Assembly is not to investigate and consider these statements - but to rush through this bill ending independent supervision and audit of these Judges.

There is no provision in the new bill for compensating a new Probate Administrator or providing him with an auditing staff. Further, because of the patent conflict of his office as a Judge of Probate, he cannot properly audit himself or his fellow judges. It is clcar to me, therefore, that the bill is politically motivated and designed to open the door for further abuses. It also closes the door to any further meaningful changes in the Probate system that would be in the public interest.

It had been suggested that without an independent Probate Administrator the public is protected since they need not reelect a Probate Judge if his performance is not satisfactory. How can the public evaluate a performance that is not independently reviewed?

It has been suggested that the Judges of Probate still remain subject to the control of the Chief Justice of the Supreme Court. Since the Chief Justice has given no indication that he favors the proposed change, or that he is ready to more actively concern himself with the supervision of the Courts of Probate, would it not make sense for the General Assembly to await his request for change?

Who besides a handful of politically powerful Judges of Probate, demands this new bill? 
Attached Letter dated April 30, 1973, from Honorable Karl O. A. Zittel, Judge of Probate, District of Lyme, to Honorable James F. Bingham (House Chairman, Judiciary Committee):

RE: Your letter of April 23, 1973 concerning proposed legislation on Probate Administrator; asking for thoughts thereon.

Dear Mr. Bingham:

I am a retired Coast Guard Captain with 32 years of active duty. I mention this so that you might agree that I have some familiarity with government and its attendent bureaucracy. When I was first elected to this job in 1966, I was absolutely amazed at the lack of checks or audits by anyone. When I brought this up at an Assembly meeting, one of the prominent judges countered with the fact that judges go before the electorate every four years and that takes care of the matter. I regarded that as a non sequitur.

I believe that the present system of an independent Probate Court Administrator is an essential check and balance to the Probate Court system. In so far as my own little Court is concerned I welcome an annual inspection and careful audit of income and procedures. The duties of the Administrator should be strengthened and not weakened by part-time supervision.

While I have strongly disagreed in the past with Professor Whitman's centralization policies, removal of the courts from close contact with the citizens, and his academic prejudice that no one but a lawyer can properly administrate probate law, I must agree with his stand as stated in his letter to you of April 19, 1973.

The Bill was passed by the Senate by voice vote on May 10 and was signed into law by the Governor on May 29, 1973 to become Public Act 365. 